\title{
Human Rights and Humanity in Gandhian Perspective
}

\author{
Neela Sharma \\ Research Scholar,H.N.B. Garhwal University,Uttrakhand
}

\section{Introduction:}

Human rights are essential for any civil society. In fact it is an inalienable right of every individual because she or he is a human being. The struggle to protect and preserve human rights is as old as human civilization itself. It has been a long and slow historical process for the realization of these rights. At the very beginning the concept of human rights evolved from the Doctrine of Natural Rights in which individual have right to life, liberty and property. In the LEVIATHAN, Hobbes assume that "every man has a "right to life" and the" right to its preservation" so much so that the social contract in which every man surrender all of his right to" this man or body of man" doesn't deprive the individual of his right to life." 1 Apart from the doctrine of natural rights the roots of the concept of human rights can be traced back to Magna Carta (1215), the Petition of Rights (1628), Bills of rights (1689),American Declaration of Independence (1776), and French Revolution (1789).The humanity had faced continuous suffering and exploitation in world wars. Hence special efforts were made by the UNO to protect the human rights. Thus in 1948, the human right has been universally declared by UNO. It consists of 30 articles with its preamble. It is one of the greatest achievements for all peoples and nations. The charter of United Nation Organisation in its preamble declared "we the people of UN determine to reaffirms faith in the fundamental human rights, in the dignity and worth of human person, in the equal rights of men and women and of the nations large and small..."2 The concept of human rights is difficult to defined. Generally human rights are those rights which are essential for the existence as well as the development of human personality.

\section{Challenges to Human Rights:}

Even after the proclamation of universal declaration of human rights, the struggle for human rights is still continuous. Today, we notice the cases of violation of human rights at various levels. The prominent among these are unemployment, poverty, economic disparity, inhuman condition of work in factories, trafficking of women and children, sexual and mental harassment for working women, gender discrimination, terrorism etc. These are the major challenges to human rights in front of the whole world. Besides, violent conflict by religious fundamentalist and by militant groups is one of the acute tensions facing by every individual and nation. Fundamentalist such as Al-Qaida, Taliban in Afghanistan are the prime example, they openly engaged in violence in order to secure their fanatic goals and aspirations. It is evident from the 9/11 attacks on New York Trade Tower and Pentagon, London attacked, 26/11 Mumbai terror attacked, which threaten the whole world and create a mass violence and insecurity among the human being.

Besides the process of globalisation has also an adverse effect in human rights. Due to the rapid system of globalisation, it creates mass poverty, unemployment and economic disparity which are the major factor responsible for violation of human right. It would be pertinent to quote here Laski "Where economic disparities are glaring high, the relation among citizens will turned into masters and slaves." 3 With the emergence of industrialization, in spite of tremendous changes in the directions of development as well as rapid progress in science and technology, the modern world has failed to eradicate the problems of violence, poverty, unemployment from the world, which posed a serious challenge to the whole humanity. Although, there has been lots of development at all level but the disparity between the haves and have-nots has been increasing on one side and the violence on the other side. Under such a critical and vulnerable condition the Gandhian way of saving the humanity has become very much relevant. The appropriate and effective remedy of this violence is not counter violence rather non-violence. As Martin Luther King says that "Today, the choice is no longer between violence and non-violence. It is either non -violence or non-existence”. 4

Human Rights in Gandhian Perspective: The essence of what is to be human is expressed clearly in the life and action of Mahatma Gandhi. In his whole life he made personal sacrifices for others and he teaches us the sincerity and love of humanity. We all came across that his whole philosophy is rooted on the welfare of whole mankind. As we know that, ever human on this earth has the right to live in peace. To him, in pursuit of these human rights the only hope for the human was for every one of us to become non-violent. Gandhi was always ready to challenge the condition which destroyed peace in life. He wanted the upliftment of all human being and 
tries to protect from the various socio-politic-economic evils. His idea of 'Sarvodaya' means welfare of all, is very much connected with the modern human rights and humanity. The globalisation of the commodity markets does not bring humanity closed to peace and justice rather it may result in hostile competition which will lead to violence. Gandhi was aware of structural violence under which the mass poor people are oppressing around the world. Once Gandhi wrote to Pandit Nehru that, "I must not fear if the world today is going the wrong way. It may be that India too will go that way and like the proverbial moth burn itself eventually in the flame around which it dances more and more furiously. But is my bounded duty up to my last breath to try to protect India and through India the entire world from such a doom. The essence of what I have said is that man should rest content with what are his real needs become self- sufficient. If he does not have this control he cannot save himself. After all the world is made up of individual just as it is the drops that constitute the ocean"5. From the above quote it's clear that Gandhi was very much concern to save the humanity from violence and injustice.

Gandhian Ways to save Humanity: We are in dire need of Gandhian method for peaceful solution. His method of Non-violence is the precious gift for saving the humanity. According to him, to be human one must be non-violent. As we know that the most important threat for humanity is violence ether created by religious fundamentalist or by nuclear weapons. Under such a vulnerable situation Gandhian non-violence is the one of the best solution to protect the humanity. Gandhi always fought without weapons and he was able to get victory in different fields. To him non-violence is the force of active love and truth which seeks justice and peace for every human being. During World War II,Gandhi wrote: "If the mad race for armaments continues it is bound to result in a slaughter such as has never occurred in history. If there is a victor left the very victory will be a living death for the nation that emerges victorious. "' 6 In the due course, the war which Gandhi talks, brings the death of millions of men, women and children, the prime example is the explosion of atom bomb in Japan by USA, still suffering the innocent people. We know that the direct requirement of today is establishing global peace and this will be possible only through Gandhian non-violence. According to him non-violence is a force more powerful than any weapons in the world. The US invasion in Iraq shows the massive violation of human rights. The innocent people suffered a lot but the main concern is only for oil not for saving human rights and humanity. He argues that the ends and means should be always same.

Besides, there are numerous methods given by Gandhi for saving the human rights from poverty, unemployment and economic disparity such as decentralisation, village industry and spinning-wheel. As we know that the world today, under the system of globalisation and industrialisation made both positive and negative effect. As far as concern with negative effect it creates a lot of poverty, hunger, unemployment and economic disparity. Gandhi was a great supporter of decentralisation at grassroots level. To him the village should have their independent production and administration. He wants to uplift the poor people who are lived in village. So that, in India, we have the system of Panchayati Raj. Because of his great concern for poor people he gave more emphasis on village industry like spinning- wheel, khadi etc so that the rural people will be able to fulfil their basic needs. Due to rapid flow of industrialisation that destroys the village industry and millions of people were become unemployed and it creates a great economic disparity between rich and poor. Gandhi once said that," Anything that millions can do together becomes charged with unique power".7To him Spinningwheel as a symbol of tool for development. Though, he was not against the machinery as such but against the craze for machine.

\section{Conclusion:}

It's clear from above, that the Gandhian methods of nonviolence, decentralisation and village industry are very much relevant in the era of globalisation in order to save and protect the human rights and humanity. Its only through his system of non-violence the individual will be able to save their life from the violence. The day has come to implement the Gandhian philosophy to bring global peace which becomes a great concern for everybody. It's pertinent to quote the view of Dr Ram Manohar Lohia "If the world and humanity have to survive we will have to be with Gandhi otherwise let it run'.'8 Therefore we need a peaceful, harmonious coexistence otherwise humanity would not survive and it can be achieve through Gandhian principles.

\section{Reference}

[1]. Jain Nilanjana,"Human Rights Under Democracy", The Indian journals of political science, vol.LXVII, No.1, 2006, p. 143.

[2]. kumar Arvind(ed), Encyclopaedia of Human Rights Violence and Non-Violence ,Anmol publication pvt Ltd ,Vol-I,1998, p. 1

[3]. Dalal Rajbir singh,"Human Rights and Directive Principles of State Policy",Journals of political science,Vol.VII.2,2011,p.24

[4]. Bibudharanjan,'Relevance of Gandhian Concept of Non-Violence to Contemporary Society, World Focus, 2010, p. 229.

[5]. Radhakrishnan.N.,Vasudevan.N, Gandhi in the Global Village, Gandhi media centre, 1998,p.78-79.

[6]. Ara Zinat,"Achieving Human Rights through Non-Violence: The Gandhian Way, Journals of Gandhian Studies, Vol.V, 2007, p. 182.

[7]. Kumar Ravindra (ed), Mahatma Gandhi in the Beginning of Twenty -First Century,Gyan Publishing House, $2006, p .55$.

[8]. Pathak Y.N.,'Why is Gandhi Relevant Even Today", World Focus, 2010, p.231. 